удк 338.432

DOI: https://doi.org/10.32851/2708-0366/2021.9.15

\begin{abstract}
Лобода O.M.
кандидат технічних наук, доцент,

Херсонський державний аграрно-економічний університет ORCID: https://orcid.org/0000-0001-9826-9443
\end{abstract}

Кириченко Н.В.

кандидат економічних наук, доцент,

Херсонський державний аграрно-економічний університет ORCID: https://orcid.org/0000-0003-1721-258X

Loboda Olena, Kyrychenko Natalia

Kherson State Agrarian and Economic University

\title{
ПІДВИЩЕННЯ ЕФЕКТИВНОСТІ ПІДПРИЄМНИЦЬКОЇ ДІЯЛЬНОСТІ ЗА РАХУНОК УПРОВАДЖЕННЯ ІНТЕГРОВАНОЇ СИСТЕМИ ІНФОРМАЦІИНОГО ЗАБЕЗПЕЧЕННЯ
}

\section{IMPROVING THE EFFICIENCY OF ENTREPRENEURIAL ACTIVITY THROUGH THE INTRODUCTION OF AN INTEGRATED INFORMATION SUPPORT SYSTEM}

У статті розглянуто сутність системи інформаиійного забезпечення підприємнииької діяльності, систематизовано структуру та склад ї̈ елементів, розкрито сутність інформачійного забезпечення підприємницької діяльності. Доведено, щзо під час формування системи інформаційного забезпечення підприємницької діяльності необхідно враховувати етапні потоки інформачї, щзо забезпечує стійкість накопичення, споживання та відтворення у сучасних умовах системи інформаційного забезпечення підприємства, а також повинна бути орієнтована на підтримку та накопичення ї̈ конкурентної здатності. На основі прогресивних комп'ютерних технологій та програмних засобів із використанням інструментів інформаційної інтеграції побудовано організаційно-економічну модель інтегрованої системи інформаційного забезпечення підприємницької діяльності, щуо орієнтована на збільшення ї̈ ефективності та конкурентоздатності. Проведено аналіз особливостей сучасних інформаційних систем, щзо виявляють негативні тендениії та проблеми, які ведуть до зниження ефективності інформаційного забезпечення підприємницьької діяльності.

Ключові слова: цицфрові технологї, управлінські рішення, інформаційна система, інтегрована система, система управління, підприємнищькі структури.

В статье рассмотрена сущность системь информационного обеспечения предпринимательской деятельности, систематизировань структура и состав ее элементов, раскрыта сущность информационного обеспечения предпринимательской деятельности. Доказано, что при формировании системь информационного обеспечения предпринимательской деятельности необходимо учитыльть этапные потоки информации, которые обеспечивает устойчивость накопления, потребления и воспроизводства в современных условиях системы информационного обеспечения предприятия, а также должна быть ориентирована на поддержку и накопление ее конкурентной способности. На основе прогрессивных компьютерных технологий и программных средств с использованием инструментов информационной интеграции построена организационно-экономическая модель интегрированной системы информационного обеспечения предпринимательской деятельности, ориентированной на увеличение ее эффективности и конкурентоспособности. Проведен анализ особенностей современных информационных систем, которые проявляют негативные тенденциии и проблемы, ведущуие к снижению эффективности информациинного обеспечения предпринимательской деятельности.

Ключевые слова: ичифровые технологии, управленческие решения, информационная система, интегрированная система, система управления, предпринимательские структуры. 
The article considers the essence of the system information support of entrepreneurial activity, systematized structure and composition of its elements, reveals the essence of information support an entrepreneurial activity on the basis of studying the interpretation a concepts in scientific literature and concludes in expediency of using information system in modern computer society. Systematized structure and composition of elements the information support system, which is an important step in solving modeling problems and forming an effective information support system of the business structure. It is proved that in the formation of the system the information support of entrepreneurial activity it is necessary to take into account the stage flows of information, which ensures the stability of accumulation, consumption and reproduction in modern conditions of the information support system of the enterprise. The organizational and economic model of the integrated system of information support of business activity, which is focused on increasing its efficiency and competitiveness, is built on the basis of advanced computer technologies and software, using the tools of information integration. The analysis offeatures a modern information system which reveals negative tendencies and problems which lead to decrease in efficiency of information maintenance of business activity is carried out. Implementation, improvement and maintenance of the efficiency an information support system involves the organization and accounting of enterprise costs, that is in this regard need to assess an objective and possible options for improving the information support system of entrepreneurial activity. The algorithm of automation integrated information support system, based on the software platform, provides data aggregation and is responsible for the actions all levels of the system. This algorithm allows the system to exist, based on the use of software and hardware, for different manufacturers, and is implemented and used in business.

Key words: digital technologies, management decisions, information system, integrated system, management system, business structures.

Постановка проблеми. Із розвитком цифрових технологій спостерігається закономірне збільшення обсягів вихідної, вхідної та інформації, що обробляється, а також, як наслідок, збільшення інформатизації суспільства. Перехід економіки країни до інноваційного типу розвитку можливий лише за формування конкурентоспроможної національної інноваційної системи, особливу роль в якій грає інформатизація суспільства. Перехід до інформаційного суспільства є одним із найбільш актуальних завдань, у зв'язку зі збільшенням цифрових технологій підприємницької діяльності інформаційне забезпечення є однією зі значимих конкурентних переваг. Використання сучасних інформаційних технологій у діяльності вітчизняних підприємницьких структур $\epsilon$ важливим напрямом збільшення їх ефективності в умовах глобалізації інформаційних зв'язків. Інтенсивна інформатизація суспільства відкриває для бізнесу нові можливості та водночас потребує раціональної організації системи інформаційного забезпечення як основи для успішного розвитку підприємництва та збільшення його ефективності.

Підприємницька діяльність грає важливу роль у розвитку економіки, областей, територій та країни у цілому, визначає темп та рівень розвитку економічних систем кожного рівня, їх стабільність та стійкість до кризових змін фінансової системи [1, с. 45]. Сьогодні на практиці в підприємницькій діяльності спостерігається розрив між накопиченням та використанням інформації, з одного боку, та цілями і завданнями стратегічного розвитку цих структур - 3 іншого. Підприємництво стикається 3 особливими труднощами виживання в конкурентному середовищі, у зв'язку з чим його ефективне функціонування та розвиток залежать від якості доступної та використаної ринкової інформації, уніфіковане використання якої може забезпечити значну стратегічну перевагу серед конкурентів [2, с. 216]. Усі ці умови зумовлюють необхідність вивчення процесів, які пов'язані з перетворенням та споживанням інформації у системі інформаційного забезпечення підприємницької діяльності, що визначає актуальність теми дослідження.

Аналіз останніх досліджень і публікацій. Аналіз наукової літератури свідчить про те, що вказана проблема та сполучені з нею питання неодноразово розглядалися в економічній теорії та практиці. Дослідження вітчизняних та іноземних учених висвітлюють широке коло питань у сфері інформації, інформаційного забезпечення підпри- 
ємницької діяльності та способів його організації [3, с. 26]. Науковим дослідженням істотності та ролі підприємництва у сучасному суспільстві й вивченню різноманітних аспектів управління підприємницької діяльності в конкурентному середовищі присвячено праці таких учених, як В.В. Кириленко, Л.О. Болтянська, Л.О. Андрєєва, O.I. Лисак. Під час дослідження інтерес представили роботи у сфері інформації, інформаційних систем та інформаційного забезпечення таких учених, як С.Г. Шило, Г.В. Щербак, К.В. Огурцова. Проте проблеми впровадження, розвитку та подальшого використання інформаційного забезпечення підприємницької діяльності в конкурентному середовищі є недостатньо викладеними та потребують проведення поглиблених досліджень.

Формулювання цілей статті. Метою статті є обгрунтування та розроблення методичного інструментарію комплексної оцінки ефективності системи інформаційного забезпечення підприємницької діяльності на основі особливостей інформаційного забезпечення та визначення тенденцій і основних напрямів його розвитку.

Виклад основного матеріалу. Розвиток інформаційних технологій у сучасному суспільстві зазвичай викликає збільшення значних обсягів інформації, що приймається, передається та обробляється, а також зростання інформатизації суспільства. Під інформатизацією суспільства розумітимемо організований соціально-економічний прогрес та науково-технічний прогрес створення оптимальних умов для забезпечення інформаційних потреб та реалізації прав і можливостей громадян, органів державної влади, органів самоврядування, організацій, суспільних об'єднань на основі формування та використання інформаційних ресурсів [4, с. 112]. Формування та використання інформаційних ресурсів, своєю чергою, реалізується в інформаційних системах завдяки реалізації інформаційних технологій, які формують інформаційне забезпечення шляхом пошуку, збору, збереження, обробки та уявлення інформації, необхідної для розроблення та прийняття управлінських рішень у підприємницькій діяльності. Термін «інформаційне забезпечення» розуміється нами як процес створення інформаційних умов для забезпечення інформаційних потреб управлінських процесів та вирішальних завдань підприємницької діяльності, у зв'язку з чим інформаційне забезпечення включається в комплексне рішення багатьох завдань управління підприємницькою діяльністю [5, с. 64-68], насамперед це облік, аналіз та прийняття рішень. Як показав аналіз існуючих у науковій літературі термінів поняття «інформаційна система», переважна більшість із них схожа в одному: інформаційна система призвана представляти інформацію, тобто інформаційна система не розкриває повною мірою суті подібних систем, оскільки основною метою та призначенням інформаційних систем є не лише представлення інформації, а й задоволення інформаційних потреб для розроблення та прийняття управлінських рішень у ході реалізації підприємницької діяльності [6, с. 89].

У процесі створення системи інформаційного забезпечення підприємницької діяльності враховуються структура, різнохарактерність та різноплановість інформації, а також ії недолік, що, своєю чергою, оказує вплив на структуру інформаційної системи. Структуру системи інформаційного забезпечення зазвичай уявляють у вигляді деякого набору взаємодіючих підсистем. Вивчення та узагальнення існуючих понять на склад та внутрішню організацію системи інформаційного забезпечення підприємницької діяльності дали змогу уточнити структуру та склад її елементів (рис. 1).

Сьогодні суб'єкти підприємницької діяльності в боротьбі за конкурентні переваги найчастіше створюють інформаційні системи, щоб стати більш ефективними та нарощувати фінансові ресурси. Інформаційне забезпечення управлінських рішень це об'єктивна необхідність конкурентоздатної підприємницької діяльності в ринковій економіці. Систематизація структури та складу елементів $є$ важливим етапом у вирішенні завдань моделювання та формування ефективної системи інформаційного забезпечення підприємницької діяльності. 


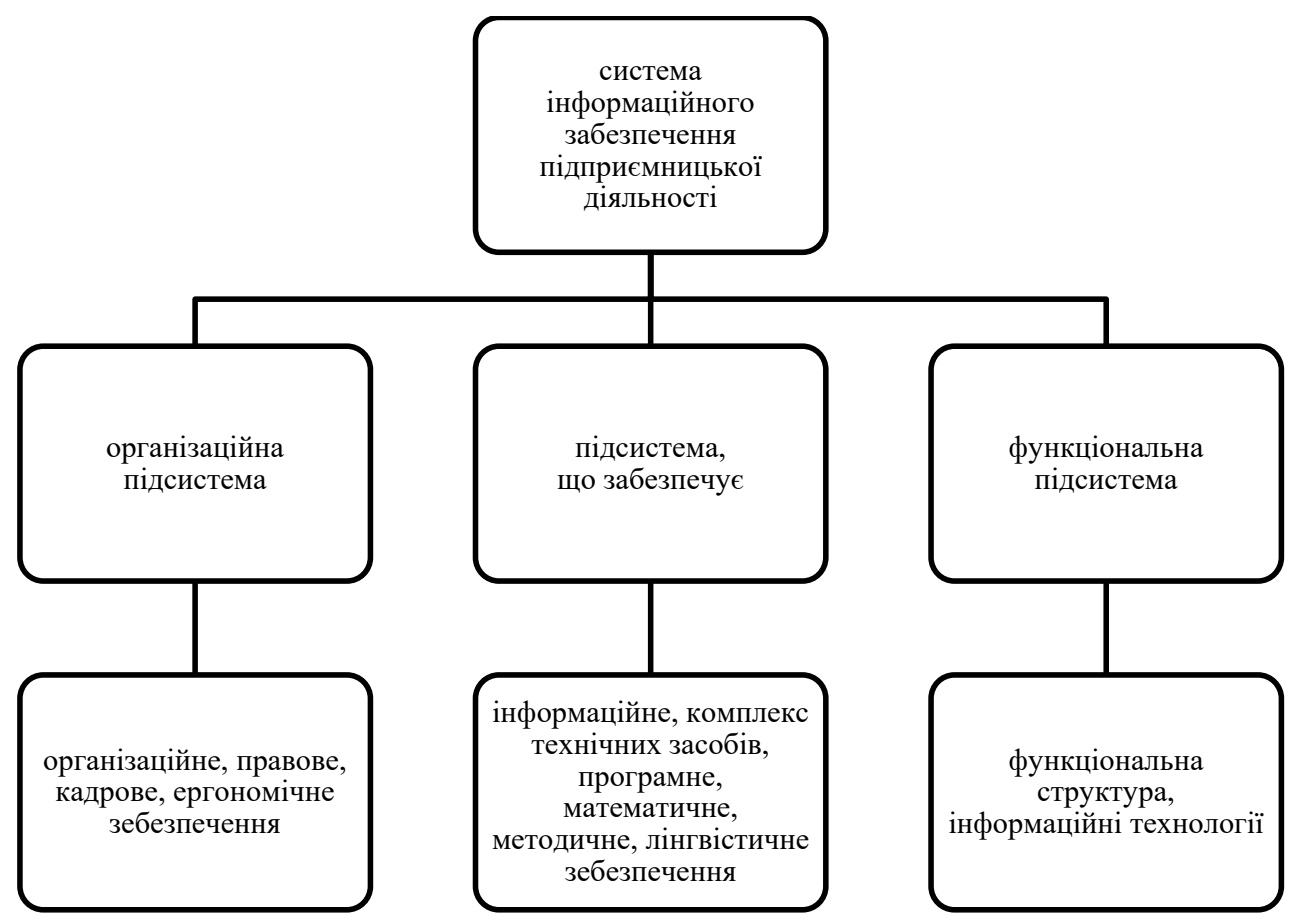

Рис. 1. Структура та склад системи інформаџійного забезпечення підприємницької діяльності

На сучасному етапі розвитку інформаційних систем і технологій інформація становиться стратегічним ресурсом, що залежить та визначає конкурентний статус підприємницької структури. Проведений аналіз практики функціонування інформаційних систем у підприємницьких структурах виявив як позитивні, так і негативні властивості. Дослідження інформаційного забезпечення діяльності підприємств підприємницького сектору виявило чисельні проблеми, що призводять до зниження ефективності інформаційних систем більшості підприємств та збереження за ними статусу сервісної служби, яка забезпечує основну бізнес-діяльність:

- багатократне дублювання інформації, комп'ютерні бази носять характер додаткового забезпечення;

- наявність невзаємопов'язаних баз даних із різною структурою, але побудованих на різноманітних принципах, у зв'язку з чим для роботи з базами потребується безліч довідників, які не поєднані єдиним стандартом;

- персонал немає кваліфікації та навиків вільно застосовувати діючі інформаційно-пошукові системи, у зв'язку з чим витрати часу на пошук необхідної інформації займають більш велику частину робочого часу;

- тривале проходження інформації між підрозділами, неефективна аналітична обробка інформації про результати діяльності;

- нераціональна структура інформаційних потоків та інформаційної взаємодії як усередині підприємницької структури, так і з зовнішніми джерелами інформації;

- інформаційна несумісна діяльність підрозділів підприємства призводить до запізнювання інформації та порушення ритму технологічного процесу й виробничого циклу;

- відсутність цілісного уявлення управлінської інформації на ринках рівня менеджменту, що призводить до зменшення ефективності управлінських рішень; 
- низький рівень надійності збереження та передачі даних, необхідність їх багатократного конвертування під час передачі від додатку до додатку.

Аналіз ситуації показав, що існуючі системи інформаційного забезпечення підприємницької діяльності здебільшого не є концептуально єдиними та не мають можливості збільшити конкурентоздатність підприємства і потребують модернізації.

Стрімке збільшення обсягу виникаючої та використаної інформації, необхідність застосування уніфікованого підходу до пошуку та обробки даних, зростання вимог до швидкості прийняття управлінських рішень, достовірності та оперативності інформації об'єктивно підтверджують необхідність використання сучасних інформаційних технологій, у тому числі необмежених можливостей і переваг комп'ютерних мереж та електронних форм уявлення інформації. Виходячи із цього, слід виділити ключові тенденції та напрями розвитку систем інформаційного забезпечення підприємницької діяльності в конкурентному середовищі [7, с. 32].

Розроблені та впровадженні системи інформаційного забезпечення підприємницької діяльності повинні володіти легко налагоджуваними можливостями, підтримувати роботу мереж та баз даних, забезпечувати сучасні стандарти управління, включати мережні можливості та Інтернет-технології, базуватися на загальновизнаних стандартах розроблення, тестування, впровадження, супроводження та сервісного обслуговування та на відповідному програмному, технічному, кадровому та документальному забезпеченні.

Інтенсивний розвиток інформаційних технологій призводить до того, що інформатизації підлягають усе нові сфери підприємницької діяльності. Розвиток системи інформаційного забезпечення в першу чергу пов'язаний із розширенням спектру досліджуваних проблем, які включають соціально-економічні проблеми та нові сфери застосування інформаційних технологій: електронну комерцію та Інтернет-управління підприємствами [8, с. 92-124].

Формування інформаційного забезпечення підприємницької діяльності являє собою процес оцінки обсягу інформації, організації інформаційних потоків, переробки інформації, інформаційної взаємодії із внутрішнім і зовнішнім середовищем та спрямований на підбор відповідних інформативних показників для використання в процесі аналізу, планування та прийняття управлінських рішень, що пов'язані 3 ефективністю здійснення підприємницької діяльності [9, с. 63-74]. Тобто доцільно використовувати можливості інтегрованих інформаційних систем, які забезпечують комплексне рішення завдань управління. Застосування інтегрованих інформаційних систем являє собою вектор розвитку та більшості підприємств та $є$ тою силою, яка може забезпечити їхню конкурентоздатність на внутрішньому та міжнародному ринках.

Інформаційне забезпечення підприємницької діяльності повинно реалізовуватися за допомогою створення інформаційного простору, яке повною мірою покликане забезпечити інформаційні потреби під час вирішення управлінських, економічних та адміністративних завдань. Відповідна інформаційна інфраструктура, створена на основі прогресивних інформаційних технологій у рамках інформаційного простору суб'єкта підприємництва, необхідна для ефективного управління підприємницькою діяльністю.

Включення інформаційних фондів у процес управління підприємницької діяльності формує ефективну технологію інформаційного обміну в системі менеджменту суб'єкта підприємництва. Найбільш доцільним є формування фондів інформації, що включають не лише виробничо-господарську, а й структуровану нормативно-довідкову, фактографічну, статистичну та іншу інформацію, яка виникає у процесі здійснення підприємницької діяльності. Для іiї перетворення слід використовувати новітні засоби та методики аналітичної обробки інформації. 
Модель інформаційного забезпечення підприємницької діяльності включає у себе дві сфери моделювання: організаційну та економічну. У рамках першої визначається сукупність організаційних відносин, які виникають у системі управління підприємницькою діяльністю, друга покликана визначати оптимальність відносин, що розглядаються, та ефективність здійснення підприємницької діяльності.

Для формування інформаційного простору підтримки підприємницької діяльності необхідно використовувати прогресивні методи збору, обробки та перетворення інформації. При цьому виявляється доцільним використовувати такі інформаційні технології: модель комунікаційних відносин, організацію інформаційних потоків та фондів, маршрутизацію потоків інформації, канали дії інформації. Суб'єкту підприємницької діяльності необхідно сформувати власну систему каталогів: організовувати інформаційні фонди, одночасно з використанням разових персональних запитів забезпечити постійне обслуговування споживачів інформації, ефективно використовувати обернений зв'язок. Особливістю системи інформаційного забезпечення підприємницької діяльності завдяки інформаційного простору є організація багатосторонніх потоків інформації, що забезпечить не лише збір, накопичення та споживання інформації, а й розширить відтворення.

Інтеграція даних передбачає побудову корпоративного сховища даних на базі існуючих інформаційних потоків та систем підтримки прийняття управлінських рішень, а також створення єдиного уніфікованого інтерфейсу для доступу до сукупності неоднорідних та незалежних джерел даних. Основним інструментом інтеграції є побудова єдиної сервісної ніші підприємства, тобто програмного забезпечення для організації централізованого управління інформаційними системами компанії на принципах сервісно-орієнтованої архітектури.

Застосування системної інтеграції дає змогу вирішити такі завдання, які пов'язані 3 інформаційно-технологічною інфраструктурою підприємства: збереження строків та трудомісткості впровадження нових систем; мінімізація витрат та збоїв під час взаємодії інформаційних систем; створення єдиної системи контролю доступу до інформації та єдиної політики інформаційної безпеки; усунення дублювання даних і функцій у системі.

На основі організації інформаційного простору розроблено організаційно-економічну модель інтегрованої системи інформаційного забезпечення, що спрямована на збільшення ефективності та конкурентоздатності підприємницької діяльності.

У результаті одержимо ефективну інтегровану систему інформаційного забезпечення підприємницької діяльності, що реалізується на базі сучасних комп'ютерних технологій та програмних засобів із використанням інструментів інформаційної інтеграції, яка орієнтована на підтримку бізнесу та збільшення конкурентоздатності як продукції, так підприємства у цілому.

Метою автоматизації інтегрованої системи інформаційного забезпечення підприємницької діяльності є зростання продуктивності та ефективності праці робітників підприємницької структури, збільшення якості інформації, сервісу та оперативності обслуговування користувачів. Існують два основних підходи до автоматизації інтегрованої системи інформаційного забезпечення: на основі комплексу програмного забезпечення та апаратних засобів одного або декількох конкретних виробників, а також на основі програмної платформи, що складається з інформаційних слоїв, які забезпечують агрегування даних і здійснюють взаємодію всіх рівнів системи.

Із метою забезпечення підприємницької діяльності в умовах конкурентного середовища нами запропоновано алгоритм функціонування інтегрованої системи (рис. 2).

Цей алгоритм дає змогу створити сучасну інформаційну систему та значно збільшити ефективність підприємницької діяльності з мінімальними витратами на кожному iз цих етапів упровадження без одночасного вкладення значних грошових засобів. 


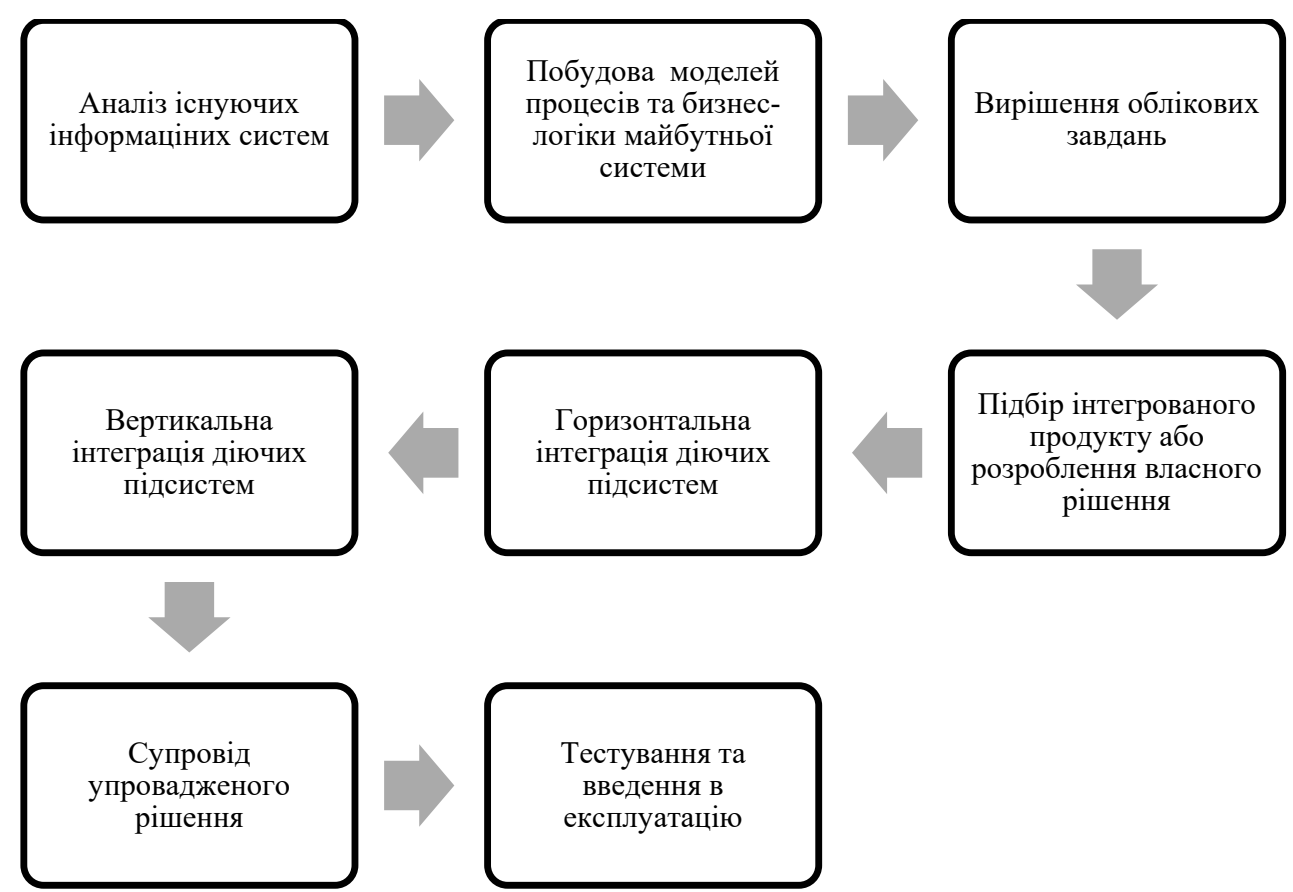

Рис. 2. Алгоритм інтегрованої системи інформаційного забезпечення

Головним підсумком упровадження інтегрованої системи інформаційного забезпечення буде вихід підприємницької структури на якісно новий рівень планування та управління своєю діяльністю, що веде до збільшення ефективності та конкурентоздатності функціонування в конкурентному середовищі.

Проведений аналіз особливостей сучасних інформаційних систем виявив негативні тенденції та проблеми, які ведуть до зниження ефективності інформаційного забезпечення підприємницької діяльності. Упровадження або вдосконалення систем інформаційного забезпечення підприємницької діяльності, а також підтримка їх ефективності та працездатності, як правило, передбачають істотну реорганізацію підприємницької структури та значні витрати. Тобто виникає об' єктивна необхідність оцінки ефективності кожного з можливих варіантів удосконалення інформатизації підприємницької діяльності: впровадження нової системи інформаційного забезпечення або реорганізація існуючої.

Досліджені методи та моделі дають змогу оцінити ефективність упровадження та подальшого функціонування інформаційних систем із різних позицій і можуть бути застосовані до різних типів підприємств та організацій. Однак для підприємницької діяльності достовірний розрахунок ефективності системи інформаційного забезпечення вкрай трудомісткий за відсутності у підприємницьких структурах необхідності обсягу облікових даних. Таке дослідження здатне перейти у масштабний проєкт, для якого потрібне збільшення додаткових ресурсів та спеціалістів. Необхідно використовувати комбінації якісних та кількісних методів аналізу ефективності [10, с. 85], які адаптовані до специфіки підприємницької діяльності 3 погляду повноти оцінки та мінімізації затрат на іiї проведення. На основі цього пропонується така комбінація методів та моделей [11, с. 289] у рамках єдиної методики оцінки ефективності системи інформаційного забезпечення підприємницької діяльності. 
У дослідженні запропоновано методику комплексної оцінки ефективності системи інформаційного забезпечення підприємницької діяльності, яка складається $з$ таких етапів:

1. Модель оцінки сукупності вартості системи інформаційного забезпечення (CI3) має вигляд:

$$
B_{C I 3}=\sum B_{n p}+\sum B_{\text {непр } 1,2},
$$

де $B_{n p}$ - загальні прямі витрати на впровадження CI3; $B_{\text {непр1,2 }}-$ непрямі витрати на впровадження CI3; $B_{\text {непр } 1}$ - вартість збитку від помилок у роботі системи; $B_{\text {непр } 2}-$ вартість витрат, які виникають залежно від людського фактору.

Спрощена модель СІ3:

$$
\begin{aligned}
& B_{C I 3}=B_{K T}+B_{I I 3}+B_{\text {всm }}+B_{\text {nidp }}+B_{3 \sigma}, \\
& B_{\text {вст }}=B_{\text {спеи }}+T_{\text {всm }}+n\left(\text { nepiod } * K_{\text {nерез }}+1\right) \text {, } \\
& B_{\text {niдp }}=T_{\text {niंp }}+B_{\text {nìp }}, \\
& B_{3 б}=\sum Ц_{3 \sigma} *\left(T_{\text {вст }}+T_{\text {очік }}\right) * \text { nеріод } * K_{3 \sigma},
\end{aligned}
$$

де $B_{K T}$ - вартість цифрових технологій; $B_{\Pi 3}$ - вартість програмного забезпечення; $B_{\text {всm }}$ - вартість встановлення програмного забезпечення; $B_{\text {niдp }}$ - вартість підтримки та обслуговування; $B_{36}$ - вартість збитків через помилки в роботі системи; $B_{\text {спеи }}$ - витрати на один час роботи спеціаліста; $T_{\text {вст }}$ - час встановлення однієї копії ПЗ; $n$-кількість копій П3; період - період експлуатації; $K_{\text {перез }}$ - коефіцієнт середньої кількості перезавантаження ПЗ за рік; $T_{n i p}-$ час підтримки; $B_{n i \partial p}-$ вартість підтримки; $\bigsqcup_{\text {зб }}-$ недоотриманий прибуток підприємства за час непрацездатності системи; $T_{\text {вст }}-$ час встановлення працездатності конкретного ПЗ; $T_{\text {очік }}$ - середній час очікування 3 моменту виникнення помилки до виправлення; $K_{3 б}$ - коефіцієнт, що визначає середню кількість несправностей за рік.

2. Визначення ефекту від упровадження СІ3:

$$
N P V=\sum_{i=1}^{n} \frac{C_{i}}{(1+k)^{i}}-\sum_{i=1}^{n} \frac{I_{i}}{(1+k)^{i}},
$$

де $N P V$ - чистий приведений дохід; $C_{i}$ - грошовий потік доходів у кінці першого періоду; $I_{i}$ - інвестиційні витрати в $i$-й період; $k$ - ставка дисконтування.

3. Визначення дисконтованого строку окупності:

$$
D P P=\sum_{i=1}^{n} \frac{C_{i}}{(1+k)^{i}} \geq I_{0},
$$

де $I_{0}$ - початкові інвестиції; $C_{i}$ - грошовий потік у період $i ; n-$ кількість періодів окупності інвестицій у проєкт.

У статті досліджено діяльність та систему інформаційного забезпечення підприємства, що займається підприємницькою діяльністю, аграрного сектору Херсонської області. Як виявив аналіз, інформаційна система підприємства має низку істотних недоліків та потребує удосконалення. Для збільшення ефективності системи інформаційного забезпечення запропоновано два проєкти: інвестування та модернізацію діючих елементів системи інформаційного забезпечення; інвестування в інтеграцію та впровадження нових елементів системи інформаційного забезпечення.

По кожному проєкту були прораховано бізнес-плани, розроблено інвестиційні проєкти та прогнози руху грошових засобів. Результати проведеного аналізу фінансових показників проєктів демонструють їх економічну вигідність та більш високий прибуток першого проєкту. Однак цей вибір може стати помилковим для підприємства, тому що згідно із запропонованою методикою далі необхідно провести оцінку 
витратних частин по моделі. Проведені розрахунки показують, що перший проєкт $\epsilon$ більш витратним, та наступним етапом є оцінка ефективності впровадження проєктів удосконалення системи інформаційного забезпечення. Проте другий проєкт є більш вигідним для фінансування. Таким чином, запропонована методика виключає помилковий вибір, який оснований на загальному аналізі фінансових показників проєктів, i необхідно підібрати оптимальний варіант збільшення ефективності системи інформаційного забезпечення підприємницької діяльності.

Висновки. У статті обгрунтовано та розроблено методичний інструментарій комплексної оцінки ефективності системи інформаційного забезпечення підприємницької діяльності на основі особливості інформаційного забезпечення та визначення тенденцій і основних напрямів його розвитку. Алгоритм інтегрованої системи інформаційного забезпечення на базі програмної платформи забезпечує агрегування даних та відповідає за взаємодію всіх рівнів системи. Цей алгоритм дає змогу виконати автоматизацію системи на основі застосування програмного забезпечення та комп'ютерних засобів різних виробників, у тому числі впроваджених та використовуваних у підприємницькій діяльності. Запропонована методика комплексної оцінки ефективності системи інформаційного забезпечення базується на адаптації до специфіки підприємництва оптимальної комбінації якісних і кількісних методів аналізу ефективності інвестиційних проєктів, якими виступають рішення з упровадження системи інформаційного забезпечення підприємницької діяльності. Особливістю запропонованої методики є те, що вона враховує особливості конкретної підприємницької діяльності, традиції застосування інформаційних технологій, економічні та технічні характеристики рішення і його економічний ефект, що є оптимальним із погляду іiї повноти та мінімізації витрат на проведення.

\section{Список використаних джерел:}

1. Кириленко В.В. Економіка : навчальний посібник. Тернопіль : Економічна думка, 2002. $193 \mathrm{c}$.

2. Болтянська Л.О., Андрєєва Л.О. Економіка підприємства : навчальний посібник. Херсон : Олді Плюс, 2015. 668 с.

3. Шило С.Г., Щербак Г.В. Інформаційні системи та технології : навчальний посібник. Харків : ХНЕУ, 2013. 220 с.

4. Марасанов В.В., Пляшкевич О.М. Основи теорії проектування і оптимізації макроекономічних систем. Херсон : Айлант, 2002. 190 с.

5. Лобода О.М. Вирішення задачі ідентифікації структури управління підприємством. Сучасна спещіальна техніка. 2012. № 3. С. 64-68.

6. Збарський В.К., Мацибора В.І. Економіка сільського господарства : навчальний посібник. Київ : Каравела, 2009. 264 с.

7. Вітлінський В.В. Моделювання економіки : навчальний посібник. Київ : КНЕУ, 2003. $408 \mathrm{c}$.

8. Танклевська Н.С., Кириченко Н.В. Активізація та ефективність впровадження інновацій аграрними підприємствами : монографія. Херсон : Грінь Д.С., 2015. 216 с.

9. Грановська В.Г., Крикунова В.М. Організаційні трансформації в аграрному секторі економіки України. Економіка АПК. 2018. № 3. С. 63-74.

10. Кузубов М.В., Єдинак О.М. Моделювання економічних і еколого-економічних процесів. Київ : КСУ, 2010. 170 с.

11. Стеценко І.В. Моделювання систем. Черкаси, 2010. 399 с.

\section{References:}

1. Kyrylenko, I.O. (2002), Ekonomika [Economy], Ekonomichna dumka, Ternopil, Ukraine.

2. Boltyanska, L.O. and Andreeva, L.O. (2015), Ekonomika pidpryiemstva [Economics of the enterprise], Oldiplus, Kherson, Ukraine.

3. Shilo, S.G. and Shcherbak, G.V. (2013), Informatsijni systemy ta tekhnolohii [Information systems and technologies], KNEU, Kharkiv. Ukraine. 
4. Marasanov, V.V. and Pliashkevych, O.M. (2002), Osnovy teorii proektuvannia i optymizatsii makroekonomichnykh system [Foundations the theory design and optimization of macroeconomic systems], Kherson, Ukraine.

5. Loboda, O.M. (2012), "Solving the problem of identifying the management structure of the enterprise", Suchasna spetsialna tekhnika, vol. 3, pp.64-68.

6. Zbarskyj, V.K. and Macybora, V.I. (2009), Ekonomika silskogo gospodarstva [Economics of agricultural enterprises], Kyiv, Ukraine.

7. Vitlinskyj, V.V. (2003) Modeliuvannia ekonomiky [Economic modeling], KNEU, Kyiv, Ukraine.

8. Tanklevska, N.S. and Kyrychenko, N.V. (2015) Aktyvizatsiia ta efektyvnist vprovadzhennia innovatsii ahrarnymy pidpryiemstvamy [Activation and efficiency of introduction innovations by agricultural enterprises], Hryn D.S., Kherson, Ukraine.

9. Hranovska, V.H. and Krykunova, V.M. (2018), "Organizational transformations in the agrarian sector of the Ukrainian economy”, Ekonomika APK, vol. 3, pp. 63-74.

10. Kuzubov, M.V. and Yedynak, O.M. (2010), Modelyuvannya ekonomichnyh i ekologo-ekonomichnyh procesiv [Modeling economic and environmental-economic processes], KSU, Kyiv, Ukraine.

11. Stecenko, I.V. (2010) Modeljuvannja system [System modeling] Cherkasy, Ukraine. 